\title{
ASSESSMENT OF THE STABILITY OF INSURANCE COMPANIES: THE CASE OF BALTIC NON-LIFE INSURANCE MARKET
}

\author{
Ilze ZARIN̦A ${ }^{1}$, Irina VORONOVA ${ }^{2}$, Gaida PETTERE ${ }^{3}$ \\ ${ }^{1,2,3}$ Riga Technical University, Riga, Latvia \\ Corresponding author's e-mail: ilzezarina@inbox.lv
}

\begin{abstract}
The study gives an overview of the Baltic non-life insurance market. The purpose of the research is to summarise stability statistics on solvency ratios, risk profiles and capital surplus, which was contained in Solvency and Financial Condition reports (SFCR) in 2016 published first time by non-life insurance companies in European Union and Baltic market (Latvia, Estonia, and Lithuania). Solvency II came into effect in 2016, and these reports have been prepared using the new requirements of the Solvency II framework. All non-life insurance companies are required to have eligible own funds at least equal to solvency capital requirement (SCR) in order to avoid supervisory intervention (own funds divided by SCR are required to be at least $100 \%$ ). The SCR is based on well known risk measure value at risk with $99.5 \%$ confidence level over a one-year time horizon. Baltic non-life insurance companies were strong capitalized (median $155 \%$ ) in 2016. It means that all Baltic companies can survive even if 1 in 200 years events have occurred although Baltic solvency coverage ratio is lower than the median ratio in European Union (209\%). For Latvian non-life insurance market, solvency ratio median is the lowest in European Union comparing by countries. The authors have analysed the historical development of the market and have calculated financial ratios, Gini's concentration index, as well as dissimilarity index. The authors have investigated the current and future internal and external risks and issues for the Baltic nonlife insurance market, such as political environment, low-yield environment, and market competition due to new mergers and acquisitions (M\&A) activities, and a new rule for accounting for insurance companies IFRS17.
\end{abstract}

Keywords: Capital management, non-life insurance, risk management, Solvency II Directive.

\section{INTRODUCTION}

Baltic non-life insurance market leaders continue to grow at a rapid pace and business growth in 2016 in gross premiums written in 10 percentages (more than Baltic GDP growth). Market has huge growth potential (analyzing average premiums and comparing with other EU countries), and market is relatively young ( 20 years). The analysis of M\&A transactions and reorganizations indicates that the Baltic insurance market is also interesting to foreign investors. Solvency II framework has been in effect for over a year now. 
Companies globally have invested significant human resources in this framework while the preparatory work was done already years ahead. By collecting data and other relevant information from public reports, the authors were able to calculate and compare the different ratios and aspects of Baltic and European Union companies.

The goal of this research is to summarize stability statistics on solvency ratios, risk profiles, and capital surplus under Solvency II framework.

The object of the paper is insurance companies' stability. The subject is the assessment of the stability of insurance companies under Solvency II framework.

The authors thus propose the following hypotheses for the study:

H01: There is a high concentration index in the Baltic market;

H02: There is a significant relationship between solvency coverage and market share;

H03: Investment structure is more conservative than that of the EU market;

H04: Companies stepping into Solvency II framework have not increased equity;

H05: Baltic non-life market does not use internal or partial internal models, and non-life risk has the highest share in risk profile (using standard formula).

The rest of this paper is structured as follows: first, there is the methods section, where stability definition and Solvency framework development are described; second, there is the stability assessment result section, where the hypothesis is either accepted or rejected; and, third, there is a short conclusion, problems that arise by authors, and what would be future studies about.

\section{METHODS}

Solvency and other financial stability aspects of Baltic non-life insurance companies have not been widely researched under the new Solvency II framework. A. Linartas (2012) has investigated the financial stability of insurance companies in Lithuania under Solvency I framework. Since 2005, European Insurance and Occupational Pensions Authority (EIOPA) biannually publishes Financial Stability report for the entire EU market. The EIOPA has a Financial Stability Committee, which draws together experts from national supervisory authorities monitoring and assessing risks and vulnerabilities with a view to facilitating. New supervisory monitoring tools and frameworks have been developed for insurance sector under the Solvency II framework. It can be seen already comparing the reports of 2005 versus 2017 and the used methods. The Baltic insurance market is currently being supervised and monitored by Lietuvos bankas (Lithuania), Finanšu un kapitāla tirgus komisija (Latvia) and Finantsinspektsioon (Estonia).

Several researchers have developed key financial stability elements or have solved separate financial stability issues. C. Campagne (1973) established the first solvency assessment for non-life companies. R. Massey (2002) introduced the analysis of insurance defaults, and Cummins and Phillips (2005) analysed the cost of equity capital in the non-life insurance market.

There is no common definition of stability for insurance sector and no prevailing analytical framework for assessing the stability of financial systems. But 
there is no doubt that the definition comparing the financial and non-financial sector (or banking and insurance sector) has different definitions. The definition of financial stability for insurance sector must, for instance, include the nature of its activity and insurance risks such as biometrical, lapse and longevity. Amongst others, Roger Ferguson (2002, Board of Governors of the U.S. Federal Reserve System), John Chant (2003), Andrew Large (2003) and other experts and organizations have been defining financial stability by applying its opposite instability (or systemic risk).

For the assessment of financial stability, EIOPA has included the following elements in their Financial and Stability report (2017): key developments regarding market risk and other threats (external risks), changes in own funds, profitability (ROE, ROI, ROA), solvency, future legislation changes (external risk), and risk assessment by SCRs, investments, and EU-wide stress test results. These key elements correspond to the findings of A. Linartas (2012) and the Geneva Association Systemic Risk Working Group (2010).

There are four main financial stability measurement approaches defined by International Association of Insurance Supervisors: simple factor based, risk factor based, scenario based, and principles based. Solvency I structure of capital requirements was based on simple factor measurement approach and was easy to apply. Market risks were not included in this structure; therefore, companies could do high risk investments without facing direct capital charge. René Doff (Doff, 2015) collected data and found out that in early 2000s, when many companies went bankrupt, some large EU companies also used alternative models such as cash flow based model Swiss Solvency Test. Under Solvency I framework, these companies were overcapitalized but alternative models helped to do a much more precise risk assessment. In 2005, the capital positions of some large European companies were as high as $326 \%$ (Munich Re), $329 \%$ (Swiss Re), or $307 \%$ (Allianz).

Under the Solvency II framework, an insurer is solvent if the company has its own funds amounting at least the same as the SCR. SCR equals a volume that can cover an event that occurs no more often than once in every 200 cases or with a surviving probability of at least $99.5 \%$ for the following 12 months. It means that solvency coverage shows stability in the short term. SCR structure and formula can been seen in Fig. 1.

$$
S C R=\sqrt{\sum_{i j}\left(\operatorname{Corr}_{i, j} * S C R_{i} * S C R_{j} * S C R_{\text {intangibles }}\right)}+S C R_{\text {operational }},
$$

where

$\operatorname{Corr}_{i, j}$ - correlation matrix between $i$ and $j$ risk;

$S C R_{i}$ - SCR for market ( $m k t$ ) (or default (def), life, health, non-life $(n l)$ );

$S C R_{\text {intangibles }}-\mathrm{SCR}$ for intangibles;

$S C R_{\text {operational }}-\mathrm{SCR}$ for operational risk. 


\begin{tabular}{|l|r|r|r|r|r|}
\hline CorrSCR & $\mathrm{SCR}_{\text {mikt }}$ & $\mathrm{SCR}_{\text {daf }}$ & $\mathrm{SCR}_{\text {liff }}$ & $\mathrm{SCR}_{\text {health }}$ & $\mathrm{SCR}_{\text {n1 }}$ \\
\hline $\mathrm{SCR}_{\text {mikt }}$ & 1 & 0.25 & 0.25 & 0.25 & 0.25 \\
\hline $\mathrm{SCR}_{\text {def }}$ & 0.25 & 1 & 0.25 & 0.25 & 0.5 \\
\hline $\mathrm{SCR}_{\text {life }}$ & 0.25 & 0.25 & 1 & 0.25 & 0 \\
\hline $\mathrm{SCR}_{\text {health }}$ & 0.25 & 0.25 & 0.25 & 1 & 0 \\
\hline $\mathrm{SCR}_{\text {n1 }}$ & 0.25 & 0.5 & 0 & 0 & 1 \\
\hline
\end{tabular}

Fig. 1. Standard formula correlation matrix (EIOPA, 2014).

The study made use of secondary data. Data was obtained from publicly available annual reports of 2015-2016 and Solvency and Financial Condition reports (SFCR) in 2016. EIOPA has published the Financial Stability Report of the EU market in July 2017. This report was used to compare key indicators in the EU market with key indicators in the Baltic market that were calculated by the authors. A descriptive research design was employed. Data collected was analysed using correlation analytical method and comprehensive method. The sampling technique adopted was purposive in nature. The study population comprises 14 non-life insurance companies in Estonia, Latvia, and Lithuania. The sample of fourteen non-life insurance companies includes Balta (2016), BTA (2016), BAN (2016), Balcia (2016), ERGO (2016), AB Lietuvos draudimas (2016), Gjensidige (2016), Swedbank (2016), Seesam (2016), Compensa (2016), Interrisk (2016), IF (2016), Salva (2016), and Inges (2016). The authors used the top seven companies by own funds: AB Lietuvos draudimas, Balcia, BTA, ERGO, Gjensidige, IF and Seesamfor third and fourth hypothesis testing.

The authors have investigated only internal financial stability factors solvency and profitability ratios (ROA, ROE, ROI, and combined ratios) - that are more deeply researched in this paper.

\section{RESULTS AND DISCUSSION}

The summary of all Baltic market gross premiums written indicates a high concentration level in market. Market share of seven companies is nearly 90 percentages while the rest of the market belongs to seven other companies (Table 1).

Table 1. Measure of inequality for non-life Baltic insurance market, 2015-2016

\begin{tabular}{|l|c|c|}
\hline \multicolumn{1}{|c|}{ Type } & $\mathbf{2 0 1 5}$ & $\mathbf{2 0 1 6}$ \\
\hline Dissimilarity index & 0.28 & 0.27 \\
\hline Gini's concentration ratio & 0.91 & 0.86 \\
\hline
\end{tabular}

Source: calculations performed by the authors based on Baltic non-life insurance companies' annual reports, 2015-2016.

Table 1 shows that concentration index has decreased in 2016 because of M\&A transaction (one company spin-off, separation into two). The authors believe that the index will continue to grow because of new M\&A transactions. Therefore, this 
study accepts the null hypothesis, H01, meaning that there is a high concentration index in the Baltic market. It signals low premiums and the lack of competition.

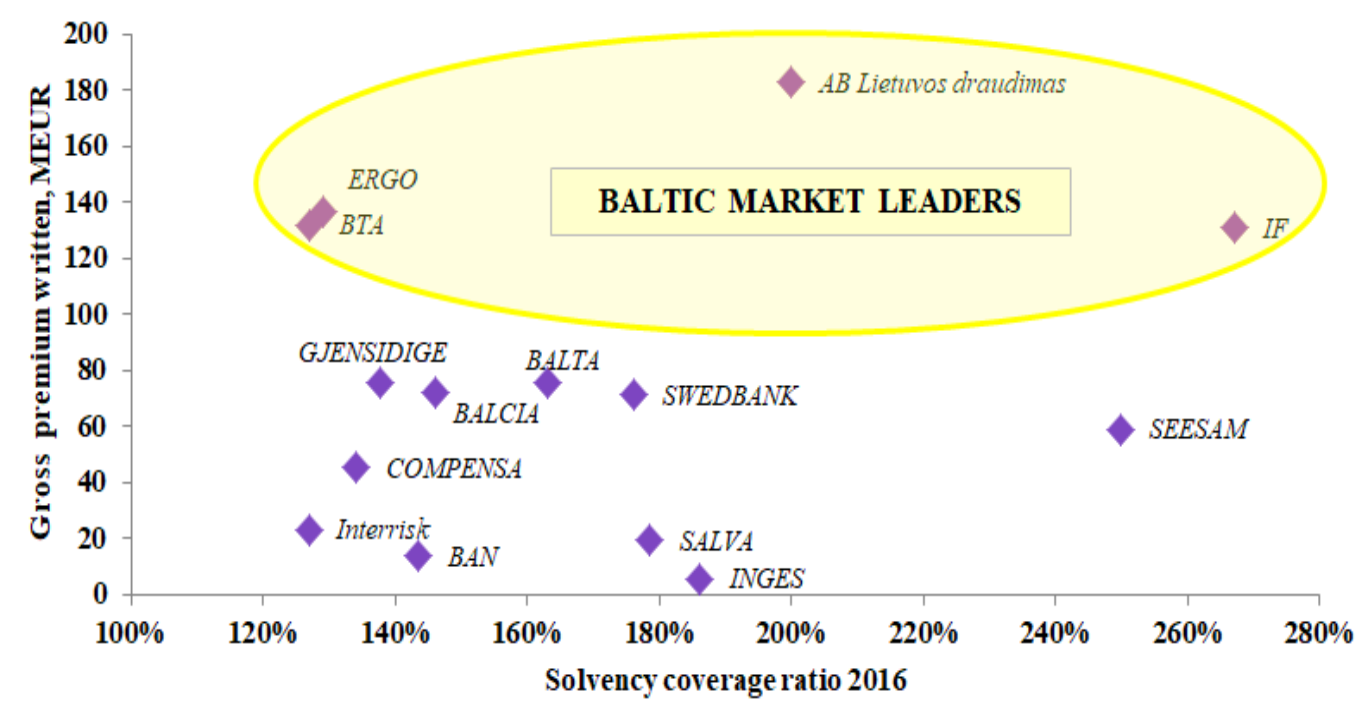

Fig. 2. Solvency II ratios 2016.

Source: calculations performed by the authors based on Baltic non-life insurance companies' SFCR reports, 2016.

The second hypothesis, H02, implies that there is a significant relationship between solvency coverage and market share (or own funds, or profit). Figure 2 clearly illustrates this relationship. There is a wide range of solvency coverage for market leaders in the Baltics. Hence, null hypothesis is rejected at the 0.05 level of significance (except for solvency coverage and own funds). Baltic non-life insurance companies were heavily capitalized (median $155 \%$ ) in 2016. Baltic solvency coverage ratio is lower than median ratio in the European Union (209\%). Solvency ratio median in the Latvian non-life insurance market is the lowest in European Union comparing by country. Table 2 illustrates Pearson correlation results if maximum and minimum profit observations are excluded.

Table 2. Pearson correlation analysis of solvency coverage

\begin{tabular}{|l|c|c|}
\hline \multicolumn{1}{|c|}{ Type } & SII ratio & SII ratio excluding max and min \\
\hline Market share & 0.18 & 0.19 \\
\hline Own funds & 0.62 & 0.66 \\
\hline Profit & 0.04 & 0.69 \\
\hline
\end{tabular}

Source: calculations performed by the authors based on Baltic non-life insurance companies' SFCR reports, 2016.

Table 3 illustrates a moderate positive correlation between solvency coverage and profit (or own funds). 
Table 3. Investment structure, percentages

\begin{tabular}{|l|c|c|r|}
\hline \multicolumn{1}{|c|}{ Asset categories } & TOP 7 Baltic & EU market & Difference \\
\hline Cash, deposits and cash equivalents & 22 & 6 & 16 \\
\hline Collateralised securities & 0 & 1 & -1 \\
\hline Collective investment undertakings & 6 & 18 & -12 \\
\hline Corporate bonds & 42 & 27 & 15 \\
\hline Equities & 1 & 21 & -20 \\
\hline Government bonds & 46 & 21 & 25 \\
\hline Loans and mortgages & 1 & 3 & -2 \\
\hline Property, plant, and equipment & 4 & 2 & 2 \\
\hline Structured notes & 1 & 1 & 0 \\
\hline
\end{tabular}

Source: calculations performed by the authors based on Baltic non-life insurance companies' SFCR reports (2016) and EU market data based on EIOPA SFCR (2016).

The third hypothesis, H03, implies that the investment structure of the Baltic market is more conservative than that of the EU market. The seven largest companies by own funds were considered in the calculations. Table 3 shows that investment structure in the Baltic market depends more on cash, deposits and government bonds than the one in the EU market. Only $1.27 \%$ ROI, low yields and low swap rates contribute to the low profitability of the market. Analysing market SCR and dividing it to risk sensitive assets indicate that companies follow different investment strategies (starting from $1 \%$ to $14 \%$ ). Companies are seeking higher yields in low-yield market using corporate bonds. Insurers act as investors supporting the Baltic state governments by capital investment amounting more than 380 MEUR. Hence, the null hypothesis is accepted.

The fourth hypothesis, H04, implies that companies complying with SII framework have not increased their equity in the process. This hypothesis was set to investigate whether companies have accumulated profit and/or if ordinary share capital has been increased under the end of Solvency I and beginning of Solvency II regimes. During 2015 and 2016, Baltic non-life insurance companies have accumulated the profit of 19 million EUR and one company has increased ordinary share capital by 34 million EUR (by 14 percentage points). Therefore, the null hypothesis is rejected. Equity increase and increase in the combined ratio (Table 4) are the main reasons why ROE decreased in 2016 (7.17 \% in 2016 against 8.92\% in 2015). The wide range of ROE can largely be explained by M\&A activity in the market.

Table 4. Key median factors for non-life Baltic insurance market, percentages

\begin{tabular}{|l|l|l|}
\hline \multicolumn{1}{|c|}{ Ratio } & $\mathbf{2 0 1 5}$ & $\mathbf{2 0 1 6}$ \\
\hline Expense ratio & 36.00 & 34.00 \\
\hline Loss ratio & 61.60 & 63.65 \\
\hline Combined ratio & 96.35 & 97.40 \\
\hline
\end{tabular}

Source: calculations performed by the authors based on Baltic non-life insurance companies' annual reports, 2015-2016. 
The fifth hypothesis, H05, states that non-life risk has the highest share in risk profile (using Solvency II standard formula) and companies do not use internal or partial internal models. Median risk profile using a standard formula for the Baltic non-life insurance companies can be seen in Fig. 3. The risk profile compared to companies is stable. Market risk has the highest standard deviation and non-life risk has the highest risk profile share (Table 5).

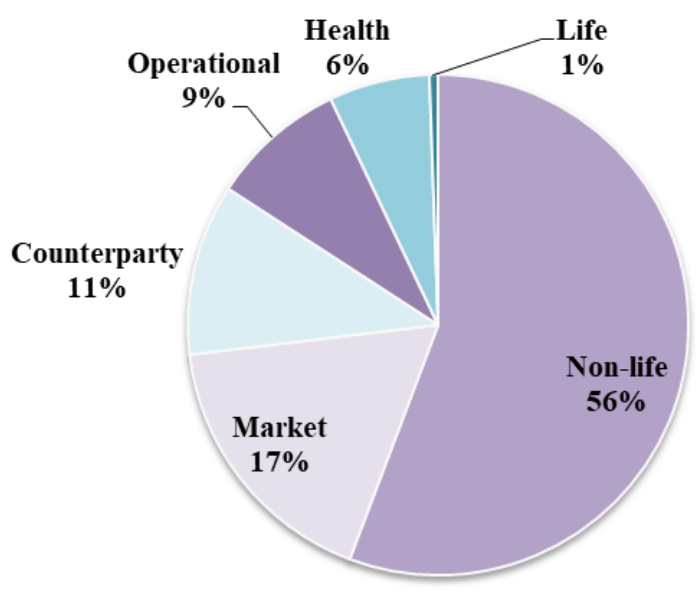

Fig. 3. Median risk profile.

Source: calculations performed by the authors based on Baltic non-life insurance companies' SFCR reports, 2016.

Table 5. Risks and profile structure

\begin{tabular}{|c|c|c|c|c|c|c|c|}
\hline \multirow[b]{2}{*}{ POSITION: } & \multicolumn{7}{|c|}{ Risks, MEUR } \\
\hline & SCR & $\begin{array}{l}\text { Non- } \\
\text { life }\end{array}$ & Market & Counterparty & Operational & Health & Life \\
\hline AVERAGE & 21.76 & 16.71 & 4.24 & 2.98 & 2.38 & 1.73 & 0.26 \\
\hline STDEV & 15.70 & 12.91 & 3.48 & 1.93 & 1.57 & 1.61 & 0.28 \\
\hline MEDIAN & 18.32 & 14.65 & 3.03 & 3.70 & 2.16 & 1.41 & 0.20 \\
\hline PERCENTILE $90 \%$ & 41.11 & 33.58 & 9.13 & 4.99 & 3.98 & 2.72 & 0.50 \\
\hline PERCENTILE $10 \%$ & 3.97 & 1.92 & 0.97 & 0.35 & 0.45 & 0.27 & 0.00 \\
\hline POSITION: & \multicolumn{7}{|c|}{ Risk profile structure, \% } \\
\hline AVERAGE & & 54 & 20 & 11 & 9 & 7 & 1 \\
\hline STDEV & & 13 & 16 & 4 & 2 & 4 & 1 \\
\hline MEDIAN & & 55 & 17 & 11 & 9 & 6 & 1 \\
\hline PERCENTILE $90 \%$ & & 68 & 39 & 14 & 11 & 11 & 2 \\
\hline PERCENTILE $10 \%$ & & 39 & 6 & 6 & 6 & 2 & 0 \\
\hline
\end{tabular}

Source: calculations performed by the authors based on Baltic non-life insurance companies' SFCR reports, 2016. 
Baltic non-life insurance companies are using only a standard formula by summarizing SFCR of the year 2016, without using alternative solvency methods (internal or partial models). Hence, the null hypothesis is accepted.

\section{CONCLUSION}

Three of the five hypotheses proposed by the authors are accepted using the correlation analysis method with 0.05 significance level or the comparing method. There is a high market concentration, the investment portfolio is more conservative than that of EU, and non-life companies do not use internal/partial internal models. Baltic non-life insurance companies were highly capitalized (median 155\%) in 2016, with the total capital surplus of 237 million EUR.

Solvency II has increase harmonization and it is easy to analyze and compare data by companies. Investments made by the Baltic insurance companies are leveraging the debt instruments. Baltic insurance market has potential to grow. Insurers should increase the return on capital. One of the main reasons why it is so low is the combination of ratio increase and economic factors - negative swap rates and low government bond yield for more than three years. Possible future external risks include political environment, cyber-crime risks, digitalization, new rule for accounting for insurance companies IFRS17, and market competition increase because of M\&A transactions. M\&A transactions can also create large SCR synergy and increase the capital surplus.

Solvency coverage ratios between market leaders in 2016 are highly deviant (138\%). Since the authors used two-year financial data (2015 and 2016) and oneyear solvency coverage analysis data (2016), further studies should be carried out using data for the following years under the Solvency II framework.

Non-life underwriting risk in risk profile has the highest share, and the relevance of standard formula to the Baltic non-life insurance market should be investigated in own risk solvency assessment process. In case the standard formula does not fit the companies' risk profile, an alternative partial/internal model should be developed. The publicly available SFCR indicates that standard formula fits and the own risk and solvency assessment (ORSA) process is not described. Companies should widen the scope of their risk assessment and deepen the risk analysis. More extensive risk assessment should be done at least for the non-life risk insurance market because half of this market is higher than 15 million EUR. This amount is significant. Suggested topics for further studies include: 'suggestion of alternative approach for non-life risk using copula approach' and 'how to choose the most appropriate type of copula for non-life risks'. Financial stability can be achieved by advancing the risk management as well as the risk assessment practices.

\section{REFERENCES}

AB Lietuvos draudimas. (2016). Annual reports (2015, 2016) and SFCR report (2016). Retrieved from https://www.ld.lt/privatiems-klientams/apie-kompanija/finansiniai-rezultatai

BALCIA. (2016). Annual reports (2015, 2016) and SFCR report (2016). Retrieved from https://www.balcia.com/about-company/financial-reports/ 
BALTA. (2016). Annual reports (2015, 2016) and SFCR report (2016). Retrieved from http://www.balta.lv/lv/par-mums/darbibas-rezultati

BAN. (2016). Annual reports $(2015,2016)$ and SFCR report (2016). Retrieved from http://www.ban.lv/kompanija/finansu-informacija/

BTA. (2016). Annual reports (2015, 2016) and SFCR report (2016). Retrieved from https://www.bta.lv/lv/about/finansu-raditaji\#-2016-gads

Campagne, C. (1961). Minimum Standards of Solvency for Insurance Firms, OECD: Paris, 1961.

Chant, J. (2003). Financial Stability as a Policy Goal. In Essays on Financial Stability, by Chant, J., Lai A., Illing M., and Daniel F. Bank of Canada. Technical Report No. 95. Retrieved from https://www.bankofcanada.ca/wp-content/uploads/2010/01/tr95.pdf

COMPENSA. (2016). Annual reports (2015, 2016) and SFCR report (2016). Retrieved from http://www.compensa.lt/content/Finansines_ataskaitos.html

Doff, R. (2015). Risk Management for Insurers (3rd ed.). The Netherlands: Risk Books.

EIOPA (2016). Financial Stability Report. Retrieved from https://eiopa.europa.eu/Publications/Reports/Financial_Stability_Report_December\%202016.pdf

EIOPA (2017). Financial Stability Report. Retrieved from https://eiopa.europa.eu/Publications/Reports/Financial_Stability_Report_June_2017.pdf

EIOPA. (2014). Technical Specification. Retrieved from https://eiopa.europa.eu/Publications/Standards/A_Technical_Specification_for_the_Preparatory_Phase_Part_I_disclaimer.pdf

ERGO. (2016). Annual reports (2015, 2016) and SFCR report (2016). Retrieved from https://www.ergo.ee/ergo/ergo-eestis/finantstulemused

Ferguson, R. (2002, September 16-17). Should Financial Stability Be an Explicit Central Bank Objective? Paper presented at the Challenges to Central Banking from Globalized Financial Systems Conference at the IMF, Washington, USA. $\quad$ Retrieved from http://www.imf.org/external/pubs/ft/seminar/2002/gfs/eng/ferguson.pdf

GJENSIDIGE. (2016). Annual reports (2015, 2016) and SFCR report (2016). Retrieved from https://www.gjensidige.lt/apie-mus/finansiniai-rezultatai

IF. (2016). Annual reports (2015, 2016) and SFCR report (2016). Retrieved from https://www.if.ee/ifist/meist/finantsandmed

INGES. (2016). Annual reports (2015, 2016) and SFCR report (2016). Retrieved from https://www.inges.ee/aruanded/2016-2/

Interrisk. (2016). Annual reports (2015, 2016) and SFCR report (2016). Retrieved from https://www.interrisk.lv/par-interrisk/finansu-raditaji/

Large, A. (2003). Financial Stability: Maintaining Confidence in a Complex World. Financial Stability Review. London: Bank of England, December, pp. 170-174.

Linartas, A. (2012). An Analysis of Insurance Companies Financial Stability and its Measurement. A Development Model for the Internationalization of SME Agro-Food of Puglia: the ISCI project, 140 - 146. Retrieved from https://mpra.ub.uni-muenchen.de/42526/1/MPRA_paper_42526.pdf

Massey, R. et al. (2002). Insurance Company Failure. Retrieved from https://www.actuaries.org.uk/documents/insurance-company-failure

Cummins, J.D. \& Phillips, R.D. (2005). Estimating the Cost of Equity Capital for Property-Liability Insurers. Journal of Risk and Insurance, 72(3), 441-478. https://doi.org/10.1111/j.1539-6975.2005.00132.x

SALVA. (2016). Annual reports $(2015,2016)$ and SFCR report (2016). Retrieved from https://www.salva.ee/et/salvast/majandustulemused

SEESAM. (2016). Annual reports $(2015,2016)$ and SFCR report (2016). Retrieved from https://www.seesam.ee/en/about-seesam/financial-results/

SWEDBANK. (2016). Annual reports (2015, 2016) and SFCR report (2016). Retrieved from https://www.swedbank.ee/about/about/reports/annual/lifeins?language=ENG

The Geneva Association Systemic Risk Working Group (2010). An Analysis of Insurance and Financial Stability. Retrieved from https://www.genevaassociation.org/sites/default/files/research-topics-documenttype/pdf_public/ga2010-systemic_risk_in_insurance_1.pdf 


\section{AUTHORS' SHORT BIOGRAPHIES}
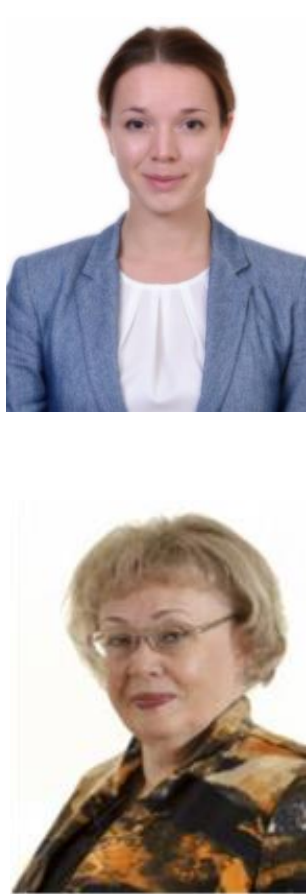

Ilze Zarina is a Ph.D. student at the Faculty of Engineering Economics and Management of Riga Technical University (RTU). She received the B.S. degree in financial engineering and the M.S. degree in actuarial analysis from RTU in 2014 and 2016 respectively. Her current research fields are risk management, actuarial modelling, reinsurance modelling, risk assessment. I. Zarina works as an Actuary in "BTA Baltic Insurance Company" in Riga, and is a Member of the Latvian Actuarial Association.

Address: Department of Innovation and Business Management, Faculty of Engineering Economics and Management, Riga Technical University, Riga, Latvia.

E-mail: ilzezarina@inbox.lv

Irina Voronova, Dr. oec., is a Professor in risk management at the Faculty of Engineering Economics and Management of Riga Technical University (RTU). She holds the Ph.D. degree in economy from the Latvian Academy of Sciences and has more than a 35-year experience of scientific and pedagogical work. Her academic publications include articles in the International Journal of Banking Accounting and Finance, Scientific Proceedings of Riga Technical University, Proceedings of the International Congress of Actuaries, and others. I. Voronova is a Member of the Board of Latvian Actuarial Association. Her current research interests include risk management, insolvency risk forecasting, and decision making.

Address: Department of Innovation and Business Management, Faculty of Engineering Economics and Management, Riga Technical University, Riga, Latvia.

E-mail: irina.voronova@rtu.lv

ORCID iD: https://orcid.org/0000-0001-5117-7111

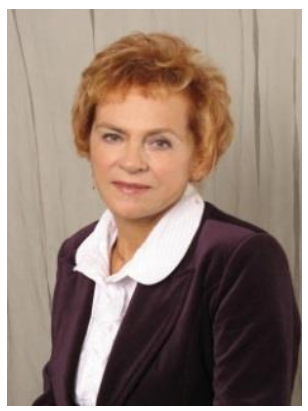

Gaida Pettere, Dr. math., is currently with the Department of Engineering Mathematics of the Faculty of Computer Science and Information Technology, Riga Technical University (RTU). She graduated from the Faculty of Physics and Mathematics of the University of Latvia in 1971 and earned the Ph.D. degree with her dissertation "Type numbers of homogenous differential equations" in 1992. From 1995, her professional activities are related to the actuarial field of insurance sector. Since 2004, she is the Chief Actuary of "BTA Baltic Insurance Company". G. Pettere was among the founders of the Latvian Actuarial Association in 1995 and has been the Chairwomen of the Association for 13 years.

Address: Department of Engineering Mathematics, Faculty of Computer Science and Information Technology, Riga Technical University, Kaļ̧̣ Street 1, Riga, LV-1658, Latvia.

E-mail: gaida@latnet.lv ORCID iD: http://orcid.org/0000-0002-1758-2188 